\title{
OS MUNICÍPIOS NO ESTADO FEDERAL BRASILEIRO
}

Algumas considerações ante a nova Lei de Diretrizes Urbanas

(Lei 10.257, de 10/07/2001)

\section{JOSÉ CARLOS VASCONCELLOS DOS REIS ${ }^{2}$}

1. Introdução. 2. O status dos Municípios no Estado brasileiro. 2.1. Breve esboço histórico. 2.2. A Constituição de 1988. 3. A repartição de competências entre os entes federativos e a política urbana. Alguns principios constitucionais aplicáveis. 3.1. O sistema de repartição de competências na Constituição de 1988. 3.2. A competência em matéria de política urbana: os principios da predominância do interesse e da subsidiariedade. 4. A Lei 10.257, de 2001, e a eficácia jurídica de suas normas. 4.1. A Lei 10.257 como lei nacional de normas gerais. 4.2. As diretrizes gerais da política urbana e seus efeitos jurídicos típicos: a eficácia principiológica. 4.3. A necessária concretização das diretrizes gerais: o papel dos Municípios na sua adaptação aos problemas locais da cidade. 5. A cidade e os instrumentos da política urbana. 5.1. A importância do Plano Diretor. 5.2. A questão do zoneamento ambiental. 5.3. A consensualidade na Administração municipal.

6. Conclusão. 7. Referências bibliográficas.

\section{Introdução}

A origem histórica da cidade, no mundo antigo, se deu pela paulatina junção de pequenos grupos, já constituídos havia muito tempo. Muitas famílias formaram a fratria; muitas fratrias, a tribo; enfim, muitas tribos, a cidade. Entretanto, embora

1 Trabalho adaptado da monografia intitulada $A$ Cidade e a Nova Lei de Diretrizes Urbanas: Lei 10.257, de 10/07/2001, laureada pela OAB-RJ com o $2^{\circ}$ lugar (categoria advogado) do $32^{\circ}$ Prêmio Jurídico Simão Isaac Benjó (março de 2002).

2 Mestre em Direito Público pela Universidade do Estado do Rio de Janeiro. Professor de Direito Constitucional da Faculdade de Direito da Universidade Cândido Mendes (Centro-RJ). Advogado no Rio de Janeiro.

R. Dir. Adm.,

Rio de Janeiro, 228: 149-176,

Abr./Jun. 2002 
sendo uma associação religiosa e política de diferentes famílias e tribos, a cidade antiga não aniquilava, em seu surgimento, aqueles grupos menores, que continuavam subsistindo com o seu próprio culto, o seu sacerdócio, a sua propriedade e a sua justiça interna. Mesmo politicamente, continuou a funcionar uma infinidade de pequenos governos, acima dos quais se colocou o governo comum da cidade. ${ }^{3}$

Desde já, uma constatação preliminar: a cidade - primeira forma de organização política de que se tem notícia - preservava a autonomia dos grupos menores que se aglutinavam para formá-la. Essa primazia das organizações menores sobre as maiores, essa preferência que devem ter, na estruturação estatal, os corpos políticos menores - no caso do Estado brasileiro, os Municípios -, será uma das idéias básicas deste trabalho.

Captando a antecedência histórica e social da cidade a organizações políticas maiores, escreve Paulo Bonavides:

“A tensão entre o município e o ordenamento estatal propriamente dito tem (...) profundas raízes históricas. Em verdade, o município, tanto quanto a família ou a tribo, antecede o Estado: é um prius; um valor dotado de mais ancianidade. $" 4$

Objeto de nosso estudo será um importante tema do Direito Público, que toca de maneira direta os Municípios, porque liga-se à ordenação do espaço nas cidades: o problema da política urbana, um dos pontos fundamentais do Direito Urbanístico, importante subdivisão do Direito Administrativo. Voltaremos nossas atenções, especialmente, à nova Lei de Diretrizes Urbanas, editada recentemente no Brasil, em 10 de julho de $2001 .^{5}$

O tema é, como se pode intuir, extremamente amplo, e apresenta inúmeras questões da mais alta relevância, cuja inteireza seria, naturalmente, impossível abarcar neste modesto trabalho. Por isso, foi necessário fazer uma radical opção temática e metodológica.

A pesquisa restringe-se à análise da situação da cidade na Federação brasileira, com ênfase em alguns aspectos interessantes da nova Lei de Diretrizes Urbanas. Não se cuidará, aqui, de um simples exame do texto legal, do Direito Positivo puramente. A mencionada Lei será estudada tendo-se sempre em vista o papel por ela atribuído à atuação do Município na matéria, com as amplas possibilidades abertas ao trabalho da Administração Pública local na ordenação justa do espaço urbano.

Parte-se de uma breve análise da posição peculiaríssima dos Municípios no Brasil, sobretudo à luz das inovações trazidas pela Constituição de 1988. A seguir,

3 A esse respeito, confira-se a obra clássica de FUSTEL DE COULANGES, Numa Denis. A Cidade Antiga. Trad. Fernando de Aguiar. 4. ed. São Paulo: Martins Fontes, 1998, pp. 134 e ss.

4 BONAVIDES, Paulo. Curso de Direito Constitucional. 9. ed. Sāo Paulo: Malheiros Editores, 2000 , p. 314.

5 A Lei 10.257 foi publicada em 11 de julho de 2001, no Diário Oficial da União, e seu art. 58 determinou a entrada em vigor após noventa dias da publicação. 
faz-se uma explanação acerca da repartição constitucional de competências, especialmente em matéria de política urbana, fixando-se o papel preponderante reservado ao Município no Estado Federal brasileiro, inclusive pela incidência do princípio da subsidiariedade, um dos mais importantes princípios políticos do Direito Administrativo contemporâneo ${ }^{6}$.

O capítulo seguinte destina-se ao estudo da eficácia da Lei 10.257, enquanto lei nacional de normas gerais. Dedicamo-nos, então, detidamente, a questões jurídicas de certa complexidade, como o próprio conceito de normas gerais e o problema de sua eficácia principiológica, com vistas a fixar o papel absolutamente necessário do legislador e do administrador municipais no que tange à sua concretização, à sua aplicação prática e, sobretudo, à sua adaptação aos problemas locais da cidade.

Finalmente, analisam-se algumas das principais repercussões práticas que a aplicação da Lei 10.257 poderá trazer para a vida e a administração das cidades, sobretudo aquelas mais densamente povoadas e socialmente heterogêneas, como o Rio de Janeiro: o relevo atribuído ao Plano Diretor municipal; o delineamento genérico de alguns importantes instrumentos da política urbana, como o zoneamento, inclusive ambiental; a busca de uma efetivação do princípio constitucional da função social da propriedade; a presença da consensualidade na condução da Administração Pública municipal.

\section{O status dos Municípios no Estado brasileiro}

\subsection{Breve esboço histórico}

No Brasil, a cidade sempre teve - numa tradição que remonta ao período colonial - um papel e um tratamento político destacado. Nossa formação histórica e cultural, herdada da colonização portuguesa, é municipalista, tendo o Município precedido a própria formação nacional. As comunas representavam, na época colonial, os grandes centros de decisão política ${ }^{7}$. E, a despeito da composição elitista e excludente, as Câmaras Municipais do Brasil-colônia, com sede nas vilas e cidades, desempenhavam as mais variadas competências e foram o único órgão que sobreviveu por inteiro, e até mesmo se fortaleceu, após a Independência. ${ }^{8}$

Não se pode desconhecer, entretanto, que, em todos os sistemas constitucionais, de natureza federativa ou unitária, a história da autonomia municipal é feita de avanços e de recuos, variando pendularmente do alargamento à contração. Liberdade e democracia exercem uma sensível influência sobre a maior ou menor amplitude

6 MOREIRA NETO, Diogo de Figueiredo. Mutações do Direito Administrativo. Rio de Janeiro: Renovar, 2000, pp. 19-21.

7 Cf. TORRES, Silvia Faber. O Princípio da Subsidiariedade no Direito Público Contemporâneo. Rio de Janeiro: Renovar, 2001, p. 241; BASTOS, Celso Ribeiro. Comentários à Constituição do Brasil, v. 1. São Paulo: Saraiva, 1988, pp. 229 e ss.

8 Cf. FAUSTO, Boris. História do Brasil. 4. ed. São Paulo: Editora da USP, 1996, pp. 64-65. 
da autonomia municipal ${ }^{9}$. As mesmas vicissitudes não deixaram de verificar-se ao longo da acidentada história do constitucionalismo brasileiro. de que se passa a fazer uma brevíssima síntese ${ }^{10}$.

Durante o Império, na vigência da Carta de 1824, os Municípios foram praticamente excluídos do texto constitucional, sendo considerados como "assunto doméstico das Províncias", numa indiferença que se manteve na Constituição Federal de 1891, primeira da República, que apenas determinou, em seu famoso art. 68, que "os Estados organizar-se-ão de forma que fique assegurada a autonomia dos Municípios em tudo quanto respeite ao seu peculiar interesse".

Deferiu-se aos Estados, desta forma, a organização dos seus respectivos Municípios, tarefa apenas limitada pelo respeito ao peculiar interesse, jamais definido com contornos objetivos. Isto representou um golpe na autonomia municipal, abandonada às conveniências políticas dos governos estaduais, que colocaram os Municípios a serviço dos interesses oligárquicos que imperaram durante toda a República Velha" ${ }^{1 !}$.

A Reforma Constitucional de 1926 incluiu a autonomia municipal entre os princípios constitucionais da União, e passou a permitir a intervenção federal no Estado que a desrespeitasse. Portanto, a autonomia local passaria a comportar uma interpretação federal, e não apenas a interpretação que lhe desse o Estado-membro no exercício do poder de organização do Município.

A Constituição de 1934 iniciou o processo emancipador do Município. Criou as condições necessárias ao florescimento do municipalismo e corrigiu os abusos cometidos, durante a República Velha, na organização plena do Município pelo Estado. Um dos grandes passos dados pela Carta de 1934 no sentido de alargar a substância da autonomia local, foi o reconhecimento, aos Municípios, de uma autonomia financeira, de modo que passaram a gozar de receitas próprias.

Durante a ditadura do Estado Novo, com a vigência da Carta outorgada de 1937, a Federação no Brasil foi meramente semântica, ${ }^{12}$ letra morta; na prática, o Brasil

9 Cf. BONAVIDES, Paulo. Op. cit, p. 313. Sobre a tendência doutrinária de aproximar, em geral, democracia e federalismo - a que se liga o problema específico da autonomia municipal -, vide, por todos, BARACHO, José Alfredo de Oliveira. Teoria Geral do Federalismo. Rio de Janeiro: Forense. 1986, pp. 53-55; DALLARI, Dalmo de Abreu. Elementos de Teoria Geral do Estado. 18. ed. São Paulo: Saraiva, 1994, pp. 219-220.

10 Para uma análise histórica mais detalhada, em cujas linhas mestras baseia-se esta exposição quase esquemática, vide HORTA, Raul Machado. Direito Constitucional. 2. ed. Belo Horizonte: Del Rey, 1999, pp. 614-631; ALVES, Francisco de Assis. Constituições do Brasil. In: Revista de Direito Constitucional e Ciência Política, n. especial. Rio de Janeiro: IBDC/Forense, 1987.

11 Cf. BASTOS, Celso Ribeiro. Op. cit., p. 231. Para a exata compreensão dos graves problemas institucionais de que o Brasil sofreu nessa época, ligados ao absoluto predomínio, na cena política, dos chamados "coronéis", em função da economia cafeeira, é indispensável a obra clássica de LEAL, Victor Nunes. Coronelismo, Enxada e Voto. 4. ed. São Paulo: Alfa Ômega, 1978.

12 A terminologia é de LOEWENSTEIN, Karl. Teoría de la Constitución. Trad. Alfredo Gallego Anabitarte. Barcelona: Ariel, 1965, p. 217 e ss., em que o autor discorre acerca de sua conhecida classificação das Constituiçōes em semânticas, nominais e normativas, distinguindo-as de acordo com sua efetividade, ou eficácia social. 
era um Estado unitário. A autonomia dos Municípios, assim como a dos Estados, embora afirmada formalmente pelo texto constitucional, era inteiramente mitigada, na prática, por um governo densamente autoritário e centralizador, concentrado de modo pessoal nas mãos de Vargas ${ }^{13}$.

A Constituição de 1946, promulgada após a queda do Estado Novo e a redemocratização do país, novamente reconheceu aos Municípios aquela autonomia já obtida com a Constituição de 1934. Definiu-lhes competências tributárias e previu a sua participação no produto da arrecadação do imposto de renda pela União. Essa participação de outras unidades de Governo no produto da receita federal atingiu estágio mais evoluído e sistemático com a Emenda Constitucional n. 18, de 1965, que criou os Fundos de Participação dos Estados, do Distrito Federal e dos Municípios.

A Constituição de 1946 também previu a defesa judiciária da autonomia municipal, conferindo ao Supremo Tribunal Federal competência para apreciar - por iniciativa do Procurador-Geral da República - as Representações de inconstitucionalidade de ato estadual lesivo à autonomia dos Municípios, o que realmente propiciou àquela Corte o desempenho de uma fecunda atividade protetora. Celso Bastos chega a vislumbrar a vigência da Constituição de 1946 como o "período róseo" do municipalismo brasileiro. ${ }^{14}$

A Constituição de 1967, e também a Emenda Constitucional n. 1, de 1969, alargaram a matéria de interesse municipal no texto da Constituição Federal, limitando a autonomia do Estado-membro nesse tema. Houve, todavia, durante os anos dos governos militares, uma intensa interferência da União - tanto no plano constitucional quanto no plano legislativo - em assuntos de interesse tipicamente municipal, uma tendência centralizadora que, aliás, foi característica daquele regime $^{15}$. Alguns exemplos de subtração da autonomia municipal pela União, na Carta de 1967/69, foram a criação de Municípios tidos como relevantes para a Segurança Nacional e a proliferação daqueles considerados estâncias hidrominerais: todos eles ficavam impedidos de eleger o seu próprio prefeito, desaparecendo, portanto, o autogoverno, um dos elementos integrantes do conceito de autonomia federativa.

13 O Estado Novo é considerado como o período de maior concentração de poderes nas mãos de uma só pessoa desde a Independência do Brasil, sem excetuar-se nem mesmo a era imperial. Reforçando a idéia de que a Federação brasileira era um simples adorno à Carta outorgada de 1937, ainda no primeiro ano do Estado Novo, Vargas teve um gesto altamente simbólico: numa cerimônia pública, queimou as bandeiras dos Estados-membros. Cf. SKIDMORE. Thomas. Brasil: de Getúlio a Castelo. Trad. coord. Ismênia Tunes Dantas. 7. ed. Rio de Janeiro: Paz e Terra, 1982, pp. 59-60.

14 BASTOS, Celso Ribeiro. Op. cit., p. 231.

15 Interessante análise da Federação brasileira, denunciando os abusos centralizadores cometidos pelo regime pós-1964, encontra-se em BARROSO, Luís Roberto. Direito Constitucional Brasileiro: o Problema da Federação. Rio de Janeiro: Forense, 1982. 
Foi a Constituição de 1988 que deu à autonomia municipal a mais avançada proteção e a mais ampla abrangência, como jamais ocorrera em momentos anteriores de nossa experiência constitucional ${ }^{16}$. Pode-se dizer que o modelo adotado pelo Brasil, a partir de 1988, não encontra paralelo em nenhuma outra Federação no mundo, nem mesmo nas mais clássicas, como a americana.

A grande inovação trazida pela Constituição vigente foi o rompimento com a tradição dual do federalismo brasileiro - desde 1891 baseado na repartição de competências entre apenas duas ordens de entidades federativas, a União e os Estados -, passando a inserir, categoricamente, os Municípios na organização político-administrativa da República Federativa do Brasil, formando-se uma terceira esfera de autonomia. ${ }^{17}$ Essa a dicção do art. 18 da Constituição Federal:

“Art. 18. A organização político-administrativa da República Federativa do Brasil compreende a União, os Estados, o Distrito Federal e os Municípios, todos autônomos, nos termos desta Constituição."

Trata-se, realmente, de concepção inédita, até 1988, em nosso Direito Constitucional Positivo. É certo que o Município teve sempre uma presença marcante em nossos textos constitucionais. Houve uma constante expansão normativa das matérias a ele consagradas nas Constituições Federais e Estaduais do período republicano, excetuando-se, evidentemente, os hiatos de autoritarismo experimentados pelo país. Não obstante isso, nossas Constituições anteriores à de 1988 sempre excluíram o Município da Federação, o que de modo algum pode ser considerado uma impropriedade: na verdade, tratava-se de uma exclusão incensurável no plano da estrutura jurídico-constitucional da forma de Estado $^{18}$.

A ausência do Município na composição do Estado Federal, aliás, é a regra geral da organização federativa. É o que se passa, por exemplo, nos Estados Unidos, no México, na Venezuela, na Áustria, na Alemanha, no Canadá, na Suíça, na Índia e na Austrália ${ }^{19}$. Na doutrina clássica, o Município é apenas um tipo de associação com direito à administração autônoma. Embora também tenham um território, súditos e um poder independente, os Municípios se distinguem do Estado porque não possuem um imperium originário, mas derivado, concedido pelo próprio Estado. Seu território é um território do Estado; seus súditos o são do Estado; seu poder, por sua

16 Cf. BONAVIDES, Paulo. Op. cit., pp. 311 e ss.

17 Id., ibid.. p. 312.

18 HORTA, Raul Machado. Direito Constitucional, cit., p. 613: BASTOS, Celso Ribeiro. Op. cit., p. 232.

19 HORTA, Raul Machado. Op. cit., p. 614. 
vez, submete-se ao do Estado. ${ }^{20}$ Trata-se de "circunscrição territorial meramente administrativa" 21 .

A atual Constituição brasileira, todavia, rompe com essa teoria tradicional. Aliás, as concepções clássicas do Federalismo têm passado por uma profunda revisão pela moderna Ciência Política. ${ }^{22}$ Veja-se, por exemplo, o que se passa com a tradicional - ou melhor, tradicionalíssima -- distinção, quanto à forma de Estado, entre Estados unitários e Estados federais, sendo aqueles caracterizados pela ausência de divisão do poder em função do território, por oposição a estes, em que o poder se reparte entre coletividades regionais autônomas. Essa distinção, embora amplamente divulgada na generalidade dos compêndios de Teoria do Estado, Ciência Política e Direito Constitucional, na verdade perde sentido, pouco a pouco, ante a realidade do Estado contemporâneo. O que se vê, na prática, é que os Estados ditos unitários, como a França, cada vez mais adquirem características fedarativas, em virtude de uma progressiva autonomização das províncias. Surge um novo tipo de organização territorial de Estado - de que a Espanha é paradigma - o chamado Estado regional, em que as Regiões autônomas - v.g., na Espanha, aquelas que têm língua própria, diversa do castelhano, a Catalunha, a Galícia e o País Basco - gozam de amplas competências e atribuições próprias, o que lhes confere uma generosa autonomia em relação ao governo central. Torna-se cada vez mais difícil cogitar de um Estado unitário puro, isto é, sem nenhum elemento de descentralização.

O Federalismo é, de fato, um fenômeno mais amplo que o Estado federal. ${ }^{23}$ As inovações trazidas em tema de status municipal pela nossa Constituição, portanto, inserem-se num contexto em que já não se pode tomar a doutrina federativa em termos absolutos e matemáticos. Em contraste com a reflexão puramente teórica, a realidade mostra uma enorme quantidade de variantes: cada país é um caso distinto, e inserto numa conjuntura histórica determinada.

A colocação dos Municípios, pela Constituição de 1988, como verdadeiros entes federativos, ao lado da União, dos Estados e do Distrito Federal, não é apenas uma alteração de forma, uma "mudança de fachada". Antes, pelo contrário, trata-se de uma opção política fundamental, que traz consequiências práticas e teóricas de grande envergadura.

Apenas para citar as mais evidentes, temos, em primeiro lugar, a Lei Orgânica municipal elaborada pela própria Câmara dos Vereadores, mediante um quorum qualificado de dois terços de seus membros (CF, art. 29), o que lhe confere uma rigidez típica dos Diplomas verdadeiramente constitucionais ${ }^{24}$, uma vez que não poderá ser alterada pelos processos legislativos ordinários.

20 Cf. JELlinEK, Georg. Teoría General del Estado. Trad. Fernando de los Ríos. México: Fondo de Cultura Económica, 2000, pp. 566-567.

21 BARACHO, José Alfredo de Oliveira. Teoria Geral do Federalismo, cit., p. 97.

22 Cf. AGUILERA DE PRAT, Cesáreo R., VILANOVA, Pere. Temas de Ciencia Política. Barcelona: Promociones Publicaciones Universitarias, 1987, pp. 266-270.

23 Id., ibid., p. 268.

24 Cf. BONAVIDES. Op. cit., p. 312. 
Além disso, goza a Lei Orgânica do Município de uma supremacia, permita-se o prosaísmo, "em miniatura", pois acha-se dotada de superioridade hierárquica sobre o ordenamento jurídico municipal, cujas normas serão inválidas se dela discreparem.

Outra consequiência importantíssima da ampliação da autonomia municipal pode ser inferida do art. 30. da Constituição, que, ao discriminar as matérias de competência dos Municípios, elevou-os a um grau de reconhecimento constitucional desconhecido, até então, no Brasil $^{25}$. A simples leitura desses três artigos citados - os arts. 18,29 e 30 -, por si só, permite afirmar que, se existe no mundo uma Constituição marcadamente municipalista, essa Constituição é a brasileira de 1988.

Em arremate deste capítulo, cumpre registrar que essa colocação do princípio da autonomia municipal, em cores tão fortes, pela nossa atual Constituição, num modelo federativo inédito no mundo, traz importantes consequiências para a tarefa de interpretação constitucional. A afirmação categórica da autonomia do Município, com a sua elevação a ente fedarativo, impõe aos intérpretes e aplicadores do Direito uma visão extremamente larga no que diz respeito à defesa e sustentação daquela garantia ${ }^{26}$.

Assim, na tarefa de interpretação e aplicação das leis em geral, especialmente aquelas que disciplinam matérias que envolvem uma atuação em conjunto de mais de uma entidade federativa - como é o caso da Lei 10.257, de 2001 -, é necessário buscar a preservação da autonomia do Município contra ingerências e usurpações ilegítimas por parte dos entes políticos maiores, inclusive lançando-se mão do princípio da interpretação conforme à Constituição. Este princípio determina, em síntese, que, quando uma norma infraconstitucional comportar diferentes possibilidades de interpretação, o Poder Judiciário deve optar por aquela que se mostrar compatível com a Lei Fundamental. ${ }^{27}$

Realmente, o Município é a "célula política essencial" da estrutura orgânica do Estado, a que se atribui a administração e execução de obras e serviços públicos de interesse local $^{28}$. Sendo o centro de poder mais próximo dos cidadãos, o Município é o nível de governo mais apto a compreender e prover, de forma mais eficaz, suas necessidades e carências, permitindo uma maior participação da população na administração local ${ }^{29}$.

Assim, serão nulos - porque verdadeiramente inconstitucionais - os atos praticados na esfera da União ou do Estado-membro que violem, de alguma maneira,

25 Id., ibid., p. 312.

26 Id., ibid., p. 314.

27 Cf. EHMKE, Horst. "Prinzipien der Verfassungsinterpretation". In: Veröffentlichungen der Vereinigung der Deutschen Staatsrechtslehrer, Heft 20. Berlin: Walter de Gruyter \& Co., 1963, p. 74-75; GARCÍA DE ENTERRÍA. Eduardo. La Constitución como Norma y el Tribunal Constitucional. 3. ed. 3. reimp. Madrid: Civitas, 1994, p. 95 e segs.; BARROSO, Luís Roberto. Interpretação e Aplicação da Constituição. 3. ed. São Paulo: Saraiva, 1999, pp. 180-187.

28 DROMI, Roberto. Ciudad y Municipio. Buenos Aires: Ediciones Ciudad Argentina, 1997, p. 11 .

29 Cf. TORRES, Silvia Faber. O Princípio da Subsidiariedade no Direito Público Contemporâneo, cit., pp. 238-239. 
aquilo que pertence à autonomia do Município, devendo tal violação ser coibida pelo Poder Judiciário, após a provocação do controle de constitucionalidade, nas suas várias modalidades. É certo que o risco de conflitos de atribuições sempre existirá; mas, caso ocorram, caberá ao Judiciário dirimi-los, pela interpretação sistemática da Constituição ${ }^{30}$.

3. A repartição de competências entre os entes federativos e a política urbana. Alguns princípios constitucionais aplicáveis

\subsection{O sistema de repartição de competências na Constituição de 1988}

Como se sabe, no Estado Federal o exercício do poder se reparte no espaço territorial, havendo uma pluralidade de organizações governamentais distribuídas regionalmente. Em regra, há uma repartição regional de poderes autônomos entre duas classes de entidades: a União (poder central) e os Estados-membros (coletividades regionais autônomas). A Federação brasileira, dentro da sistemática atual, adiciona, como vimos, um terceiro elemento: os Municípios. ${ }^{31}$

A existência de uma repartição constitucional de competências entre os entes federativos é uma das características básicas e necessárias de todo Estado Federal ${ }^{32}$. Realmente, cabe à Constituição Federal assegurar a coexistência harmoniosa entre o ordenamento central (o da União), os ordenamentos regionais (dos Estados) e, no caso brasileiro, os ordenamentos locais (dos Municípios). A Constituição cumpre esse papel, precisamente, através da repartição de competências, demarcando as matérias próprias a cada um dos entes federativos.

O sistema adotado pela Constituição de 1988 é marcado por um intenso ecletismo, em virtude da busca de um federalismo de equilíbrio no Brasil. Essa é, em linhas gerais, a repartição realizada pelo vigente texto constitucional: (a) competência geral da União (art. 21); (b) competência legislativa privativa da União, mas delegável aos Estados, mediante o cumprimento de certos requisitos (art. 22 e seu parágrafo único); (c) competência administrativa comum a todos os entes federativos (art. 23); (d) competência legislativa concorrente da União, Estados e Distrito Federal (art. 24); (e) competência de poderes residuais dos Estados (art. 25, § 1ㅇ); (f) competência de poderes enumerados dos Municípios (art. 30). ${ }^{33}$

30 BARROSO, Luís Roberto. "Meio Ambiente e Federação". In: O Direito Constitucional e a Efetividade de suas Normas: Limites e Possibilidades da Constituiçāo Brasileira. 2. ed. Rio de Janeiro: Renovar, 1993, p. 259.

31 Cf. DALLARI, Dalmo de Abreu. Elementos de Teoria Geral do Estado, cit., p. 215; BARROSO, Luís Roberto. "A Derrota da Federação: o Colapso Financeiro de Estados e Municípios". In: Temas de Direito Constitucional. Rio de Janeiro, Renovar, 2001, pp. 141-142.

32 DALLARI. Op. cit., p. 218-219; MORAES, Alexandre de. Direito Constitucional. 8. ed. São Paulo: Atlas, 2000 , p. 254.

33 Cf. MORAES, Alexandre de. Op. cit., pp. 274 e ss. 
Assim, além da peculiaridade de inserir os Municípios como entidades federativas, a Constituição de 1988 singulariza-se pelo fato de incorporar dois sistemas distintos de repartição de competências, a seguir descritos. ${ }^{34}$

O modelo clássico é aquele que foi implantado pela Constituição americana de 1787, e que tem exercido secular influência sobre várias Federações. Através deste sistema, a Constituição enumera os poderes da União e atribui aos Estados a competência residual. Vale dizer, os Estados podem exercer o seu poder sobre tudo aquilo que não se inclua entre os poderes enumerados da União. É a fórmula do art. 25, § 1으, da Constituição de 1988.

O sistema moderno originou-se da Constituição austríaca de 1920 . Consiste na engenhosa fórmula da competência concorrente: estabelece-se um rol de matérias sobre as quais todos os entes federativos poderão legislar, sendo que cabe à União a legislação de normas gerais e, aos Estados, a legislação suplementar, de normas específicas. Esse é o modelo adotado pela Constituição de 1988 no art. 24.

\subsection{A competência em matéria de política urbana: os princípios da} predominância do interesse e da subsidiariedade

A repartição constitucional da competência em Direito Urbanístico em geral pode ser resumida como se segue.

A matéria é prevista genericamente no art. 24 , inc. I:

“Art. 24. Compete à União, aos Estados e ao Distrito Federal legislar concorrentemente sobre:

I - direito tributário, financeiro, penitenciário e urbanístico".

$\mathrm{E}$, quando houver o interesse local preponderante, a competência é também atribuída aos Municípios:

“Art. 30. Compete aos Municípios:

I - legislar sobre assuntos de interesse local;

II - suplementar a legislação federal e a estadual no que couber;

(...)

VIII - promover, no que couber, adequado ordenamento territorial, mediante planejamento e controle do uso, do parcelamento e da ocupação do solo urbano".

O Direito Urbanístico apresenta-se, portanto, em três graus de especialização legiferante: (a) normas gerais da União; (b) normas regionais, suplementares, dos Estados; (c) normas locais dos Municípios, não só em virtude da competência

34 Sobre o tema, veja-se, dentre muitos outros: MIRANDA, Pontes de. Comentários à Constituição de 1946. v. I. Rio de Janeiro: Henrique Cahen Editor, 1947, pp. 54-57 e 257 e ss.; HORTA, Raul Machado. Op. cit., pp. 351 e ss.; TORRES, Silvia Faber. Op. cit., pp. 215 e ss. 
atribuída expressamente pelo inc. VIII, mas também, quando for o caso, da competência suplementar conferida pelo inc. II, do art. 30, da Constituição, sempre que o interesse local assim o requerer. Trata-se de uma solução constitucional louvada por autores como Diogo de Figueiredo Moreira Neto ${ }^{35}$.

Harmonizando-se com esses dispositivos, a Política Urbana, na Constituição, é colocada como um tema específico da Ordem Econômica e Financeira, tratado primordialmente no art. 182, cujo caput assim dispõe:

"Art. 182. A política de desenvolvimento urbano, executada pelo Poder Público municipal, conforme diretrizes gerais fixadas em lei, tem por objetivo ordenar o pleno desenvolvimento das funções sociais da cidade e garantir o bem-estar de seus habitantes."

Como se pode ver, as próprias normas constitucionais referentes à matéria já confiam, por si sós, ao Município poderosas possibilidades de ação para modelar o desenvolvimento da cidade, abrindo-lhe a perspectiva da chamada reforma urbana, através de instrumentos como o Plano Diretor, a função social da propriedade urbana e a desapropriação. ${ }^{36}$

Essa distribuição constitucional de competências entre os entes federativos em matéria de política urbana mostra-se coerente com dois importantes princípios do Direito Público: o do interesse predominante e o da subsidiariedade, ambos ocupando o alicerce da Federação.

O princípio do interesse predominante é de compreensão muito simples. Ele norteia a repartição de competências entre os entes federativos ao informar que devem caber: (a) à União as matérias de interesse predominantemente geral ou nacional (v.g. relações exteriores, segurança nacional, política monetária); (b) aos Estados, matérias de predominante interesse regional (v.g. transporte intermunicipal); (c) por fim, aos Municípios, os assuntos em que predomina o interesse local, entre os quais, inegavelmente, se inclui o urbanismo. ${ }^{37}$

O princípio da subsidiaridade também deve ser levado em conta quando da distribuição constitucional de atribuições entre as entidades que integram uma $\mathrm{Fe}$ deração. Embute, todavia, complexidade maior, e tem uma esfera de aplicação muito ampla em todo o Direito Público, e não apenas em matéria de organização do Estado. $^{38}$

35 MOREIRA NETO, Diogo de Figueiredo. Curso de Direito Administrativo. 11. ed. Rio de Janeiro: Forense, 1999, p. 396.

36 Cf. HORTA, Raul Machado. Direito Constitucional, cit., pp. 260-261.

37 MORAES, Alexandre de. Op. cit., pp. 274-275.

38 Para uma ampla análise do tema e de suas múltiplas aplicações práticas, veja-se TORRES, Silvia Faber. O Princípio da Subsidiariedade no Direito Público Contemporâneo, cit., e BARACHO, José Alfredo de Oliveira. Princípio da Subsidiariedade: Conceito e Evolução. Rio de Janeiro: Forense, 1996. 
A concepção moderna da subsidiariedade deve muito à doutrina social da Igreja Católica, afirmada de modo solene na Encíclica Quadragesimo Anno (1931), do Papa Pio XI, com o desiderato de proteger a esfera de autonomia dos indivíduos e da coletividade contra toda intervenção pública injustificada. Germinou como um princípio de organização social, com o objetivo de viabilizar o pleno desenvolvimento da pessoa humana através de um equilíbrio entre os cidadãos, a família, os corpos intermediários e o Estado. Naquela Encíclica de Pio XI, constou expressamente a idéia de que é dever da comunidade maior apoiar e estimular a comunidade menor, mas também que é uma injustiça subtrair das comunidades menores e dos indivíduos, para atribuir à comunidade maior, as tarefas que èles possam efetuar com a própria iniciativa e trabalho. Da doutrina da Igreja, o princípio da subsidiariedade migrou para o Direito Público como um dos suportes doutrinários aptos a definir a repartição de competências entre o ente político maior (e.g. a União Federal) e os entes políticos menores (os Estados e, no Brasil, os Municípios). ${ }^{39}$

Com efeito, os postulados básicos da subsidiariedade se manifestam e se realizam, de forma mais expressiva e perceptível, na estrutura de uma organização federal, na qual se encontram distintas entidades territoriais ${ }^{40}$. O princípio atuará, num Estado Federal, organizando os sucessivos graus de complexidade das entidades públicas, "de tal forma que os entes públicos menores tenham prioridade sobre os maiores para atuar na satisfação dos interesses locais; da mesma forma, a seguir, os entes públicos intermédios, para atuarem na satisfação dos interesses regionais e, ainda, os entes públicos nacionais, para atuarem na satisfação de todos os demais interesses que não possam ser satisfatoriamente atendidos pelos entes regionais" ${ }^{4 !}$.

Em suma, tudo aquilo que uma comunidade menor puder fazer por si mesma não deve ser absorvido por uma comunidade maior, garantindo-se, dessa forma, a autonomia dos Estados e Municípios em face da União ${ }^{42}$. Nesse sentido, Celso Ribeiro Bastos afirma que, num Estado Federal, o Município prefere ao Estado e à União; e o Estado, por sua vez, prefere à União ${ }^{43}$. Ou, na síntese feliz de Silvia Faber Torres, em densa dissertação sobre o tema:

“ Na estrutura federal de Estado, nada deveria ser exercido por um poder de nível superior, desde que pudesse ser cumprido pelo inferior. Isso significa dizer que só seriam atribuídas ao governo federal e ao estadual aquelas

39 Cf. TORRES, Silvia Faber. Op. cit., pp. 7 e ss.; MOREIRA NETO, Diogo de Figueiredo. Mutações do Direito Administrativo, cit., pp. 20-21.

40 Cf. TORRES, Silvia Faber. Op. cit., p. 211.

41 MOREIRA NETO, Diogo de Figueiredo. “Cidadania e Advocacia no Estado Democrático de Direito". In: Revista da Procuradoria Geral do Estado do Rio de Janeiro, n. 50, 1997, p. 118.

42 Cf. SANCHEZ AGESTA, Luís. Principios de Teoria Política. Madrid: Nacional, 1983, pp. 448-449.

43 BASTOS, Celso Ribeiro, MARTINS, Ives Gandra da Silva. Comentários à Constituição do Brasil, v. 1, cit., p. 416. 
tarefas que não pudessem ser executadas senão a partir de um governo com esse nível de amplitude e generalização." 44

Assim, a Constituição de 1988, ao atribuir ao Município autonomia política, legislativa e financeira, e ao conferir-lhe a gestão dos assuntos de interesse local, erigiu importante suporte à aplicação do princípio da subsidiariedade, permitindo que "as decisões sejam tomadas o mais próximo possível dos cidadãos" 45 .

\section{A Lei 10.257, de 10 de julho de 2001, e a eficácia jurídica de suas normas}

\subsection{A Lei 10.257 como lei nacional de normas gerais}

Em virtude da competência constitucionalmente atribuída à União em Direito Urbanístico e, mais especificamente, em política urbana, a Lei 10.257 deve ser interpretada e aplicada como uma lei nacional, restringindo-se o seu conteúdo material a normas gerais referentes ao tema que disciplina. E isto se dá em decorrência de expressa disposição do art. 182 - que limita a competência da União, nesta matéria, às diretrizes gerais da política urbana -, além da atribuição de competência concorrente à União, aos Estados e ao Distrito Federal, em tema de Direito Urbanístico (art. 24, inc. I). Assim, a legislação da União limita-se às normas gerais, cabendo àquelas outras entidades federativas a edição de normas específicas.

A necessária caracterização da Lei 10.257 como lei nacional de normas gerais traz expressivas repercussões sobre o papel atribuído aos Municípios pela Constituição, que será analisado mais adiante. Neste passo, cumpre esclarecer, brevemente, um conceito muito difundido e utilizado, mas de difícil delimitação teórica e prática: o próprio conceito de normas gerais. Esse esclarecimento prévio é imprescindível para a exata compreensão da eficácia jurídica da Lei 10.257 .

$\mathrm{O}$ conceito de normas gerais - nas quais se exaure a competência da União em matéria de política urbana - não é de fácil definição: ao contrário, desde a sua primeira menção, na Constituição de 1934 , tem sido um verdadeiro "tormento para os intérpretes" 46 .

Todavia, já se chegou a algum consenso nesta matéria. Sem pretender realizar um amplo levantamento doutrinário a respeito do tema, valemo-nos da síntese de Diogo de Figueiredo Moreira Neto, que elencou os principais critérios para a identificação das normas gerais, presentes na melhor doutrina juspublicística brasileira ${ }^{47}$. São suas características:

44 TORRES, Silvia Faber. Op. cit., p. 213.

45 Id., ibid., p. 241.

46 BARROSO, Luís Roberto. "Apontamentos sobre o Princípio da Legalidade". In: Temas de Direito Constitucional, cit., p. 185.

47 MOREIRA NETO, Diogo de Figueiredo. "Competência Concorrente Limitada: o Problema da Conceituaçāo das Normas Gerais". In: Revista de Informação Legislativa, 100/127, 149, apud 
(1) Estabelecem princípios, diretrizes, linhas mestras (conforme Pontes de Miranda, Alcino Pinto Falcão, José Afonso da Silva e Cláudio Pacheco).

(2) Não podem entrar em pormenores ou detalhes nem, muito menos, esgotar o assunto legislado (segundo os mesmos autores).

(3) Devem referir-se a questões fundamentais (Pontes de Miranda e Adilson Dallari).

(4) Não são normas de aplicação direta (Cláudio Pacheco, Geraldo Ataliba).

Em virtude dessas caracteríticas, as normas gerais - como aquelas veiculadas na Lei 10.257 - produzem efeitos jurídicos muito peculiares, que serão objeto do tópico seguinte.

\subsection{As diretrizes gerais da política urbana e seus efeitos jurídicos típicos: a eficácia principiológica}

Uma vez analisado o significado do conteúdo material da Lei 10.257 , que se restringe a normas gerais de política urbana, passa-se ao estudo de seus efeitos jurídicos típicos, isto é, de sua eficácia. ${ }^{48}$

Para o tema que aqui se desenvolve - situado na repartição de competências entre os entes federativos em matéria de política urbana —, não há diferença prática relevante entre as noções de norma geral, princípio ou norma programática. São todas espécies de normas veiculadas pela Lei 10.257 , e que produzem efeitos jurídicos análogos. O que se busca analisar, são as características básicas da chamada eficácia principiológica, i.e. os importantes efeitos produzidos pelos princípios na ordem jurídica.

Está superada a antiga distinção que se fazia entre norma e princípio, que embutia a idéia de que os princípios jurídicos não seriam normas.

Ora, tendo a função de reger comportamentos, de determinar condutas, os princípios não podem ser outra coisa senão verdadeiras normas, pertencentes ao mundo do dever ser: permitem, ordenam ou proíbem certos comportamentos. ${ }^{49} \mathrm{O}$ que se constata, na verdade, é que as normas jurídicas apresentam diferentes estruturas. Há, na ordem jurídica, normas com eficácia mais restrita, aplicáveis às situações específicas de que cogitam, e normas com um maior teor de abstração, que

BARROSO, Luís Roberto. “Apontamentos sobre o Princípio da Legalidade". In: Temas de Direito Constitucional, cit., pp. 186-187.

48 Para uma ampla análise do conceito de eficácia, como produção dos efeitos jurídicos típicos de um ato ou norma jurídica, veja-se NOVELLI, Flávio Bauer. "A Eficácia do Ato Administrativo". In: Revista de Direito Administrativo, v. 60, abr./jun. 1960, pp. 16-26, e v. 61, jul./set. 1960, pp. 15-41.

49 Dentre muitos outros: ALEXY, Robert. Teoría de los Derechos Fundamentales. Trad. Emesto Garzón Valdéz. Madrid: Centro de Estudios Constitucionales, 1993, p. 147; CRISAFULLI, Vezio. La Costituzione e le sue Disposizioni di Principio. Milano: Dott. A. Giuffrè Editore, 1952, pp. 15-16; BOBBIO. Norberto. Teoria do Ordenamento Jurídico. Trad. Maria Celeste dos Santos. 10. ed. Brasília: Ed. Universidade de Brasília, 1997, pp. 158-159; LARENZ, Karl. Derecho Justo: Fundamentos de Ética Jurídica. Trad. Luís Díez-Picazo. Madrid: Civitas, 1993, p. 197. 
desempenham um papel mais destacado dentro do sistema. ${ }^{50}$ Por isso, a doutrina moderna converge no sentido de considerar as normas como o gênero ao qual pertencem, como espécies, as regras e os princípios. ${ }^{51}$

Os princípios apresentam, todavia, a peculiaridade de não possuírem a estrutura formal típica das proposições jurídicas, que liga à pressuposição de um fato uma conseqüência jurídica. Eles apenas indicam a direção que se há de percorrer para encontrar-se a regulação adequada ao fato concreto, consagrando valores a serem preservados. Desempenham, por isso, uma importante função negativa: a exclusão de decisões contrapostas a esses valores. ${ }^{52}$

Assim, ao contrário das regras, os princípios apenas indicam a direção da consequiência jurídica, deixando os pormenores em aberto. Não estando ainda suficientemente concretizado para permitir uma subsunção, o princípio necessita de uma "normativização" ulterior. Naturalmente, este processo de contínua concretização torna fluidas as delimitações entre os princípios e as regras. ${ }^{53}$

A constatação de que há diferentes graus de abstração e generalidade entre as normas que integram a ordem jurídica - em que os princípios são as normas mais gerais, o primeiro passo na consecução de uma regulação ${ }^{54}$ - permite dizer que a atividade de interpretação do Direito "deve começar pela identificação do princípio maior que rege o tema a ser apreciado, descendo do mais genérico ao mais específico, até chegar à formulação da regra concreta que vai reger a espécie" ${ }^{55}$. Assim, conceitua-se o princípio - seja ele expresso ou implícito no ordenamento - como a norma jurídica determinante de outras, ditas subordinadas, que a pressupõem, desenvolvendo e especificando o seu preceito em direções mais particulares ${ }^{56}$.

O critério mais referido para distinguir os princípios das regras é o da generalidade: os princípios são normas de um grau de generalidade mais alto, relativamente

50 BARROSO, Luís Roberto. Interpretação e Aplicação da Constituição: Fundamentos de uma Dogmática Constitucional Transformadora. 3. ed. São Paulo: Saraiva, 1999, p. 147.

51 Nesse sentido, por exemplo: ALEXY, Robert. Op. cit., p. 83; MIRANDA, Jorge. Manual de Direito Constitucional, t. II. 3. ed. Coimbra: Coimbra Editora, 1996, p. 224; BONAVIDES, Paulo. Curso de Direito Constitucional, cit., pp. 230-231; BASTOS, Celso Ribeiro. Comentários à Constituição do Brasil, v. 1, cit., p. 340; CANOTILHO, J. J. Gomes. Direito Constitucional e Teoria da Constituição. 3. ed. Coimbra: Almedina, 1999, p. 1.086.

52 Cf. CANOTILHO. Op. cit., p. 1.107; LARENZ, Karl. Derecho Justo, cit., pp. 32-33.

53 Cf. CANARIS, Claus-Wilhelm. Pensamento Sistemático e Conceito de Sistema na Ciência do Direito. Trad. António Menezes Cordeiro. 2. ed. Lisboa: Fund. Calouste Gulbenkian, 1996, pp. 86-87.

54 LARENZ, Karl. Derecho Justo, cit., p. 36.

55 BARROSO, Luís Roberto. Interpretação e Aplicação da Constituiçāo, cit., p. 147. Outros autores também vislumbram uma espécie de "escala de concretização" do Direito, que partiria do ponto máximo de abstração que são os valores, descendo para os princípios, passando pelos subprincípios, pelas regras, até chegar-se à sentença judicial que irá reger o caso concreto. Cf. TORRES, Ricardo Lobo. Curso de Direito Financeiro e Tributário. 7. ed. Rio de Janeiro: Renovar, 2000, pp. 77 e ss.; CANARIS. Op. cit., pp. 96-99; CANOTILHO. Op. cit., pp. 1.099-1.101.

56 Cf. CRISAFUlli. La Costituzione e le sue Disposizioni di Principio, cit., p. 15. 
às regras. Mesmo a caracterização dos princípios gerais do direito, por oposição a outros princípios mais específicos, obedece a esse critério relativo e gradual. ${ }^{57}$

Por exemplo, o princípio mais genérico da função social da propriedade (CF, art. 5․ inc. XXIII) encontra especificação e concretização nos princípios mais específicos e nas regras dos arts. 182 a 186, todos da Constituição Federal. Os arts. 182 e 183 - que dizem respeito às diretrizes da política urbana no país - , por sua vez, encontraram regulamentação através da Lei 10.257, de 2001: e esta, finalmente, necessita - pela própria natureza principiológica de suas normas - de concretização através de leis municipais mais específicas, aliás expressamente requeridas em várias de suas disposições.

Mas essa concepção gradual não basta para caracterizar os princípios. Há também um aspecto qualitativo no problema: os princípios são verdadeiros comandos de otimização; vale dizer, são normas que ordenam que algo seja realizado na maior medida possível, dentro das possibilidades e limitações jurídicas e fáticas existentes. ${ }^{58}$ Essas limitações jurídicas podem ser regras que excepcionam o princípio em alguma circunstância particular, ou mesmo outros princípios de mesma hierarquia e em sentido oposto. Neste último caso, surge a necessidade de realizar-se uma ponderação, pois os princípios conflitantes não se excluem (como ocorre às regras antinômicas), mas coexistem. ${ }^{59}$

Esclareça-se a noção. Os princípios não chegam a estabelecer consequiências jurídicas que se sigam automaticamente quando satisfeitas certas condições. Apenas apontam uma direção, estabelecem um fundamento, mas não exigem uma única decisão particular, pois pode haver outros princípios que apontem na direção contrária. Desta forma, os princípios têm uma dimensão que falta às regras: a dimensão do peso ou importância, devendo ser aferido, em caso de conflito entre eles, o peso relativo de cada um no caso concreto. ${ }^{60}$

A chamada ponderação de princípios deve suas origens à Jurisprudência do Tribunal Constitucional Federal da Alemanha, que a desenvolveu a partir da segunda metade do século XX. Quando dois ou mais princípios entram em colisão, forma-se uma relação de precedência, de preponderância, que só pode ser devidamente equacionada no caso concreto: em certas circunstâncias, um dos princípios aplicáveis precederá ao outro, que cederá. O aplicador do Direito deve impor concessões recíprocas a cada um dos bens jurídicos protegidos pelos princípios colidentes, de modo a alcançar uma solução em que a restrição a cada bem seja a menor possível, sem se sacrificar inteiramente nenhum dos princípios jurídicos em jogo. ${ }^{61}$

57 Cf. ALEXY. Op. cit., pp. 83-84; CANARIS. Op. cit., p. 79; BOBBIO. Op. cit., p. 158; ASCENSÃO. José de Oliveira. $O$ Direito. Introdução e Teoria Geral: uma Perspectiva Luso-brasileira. Rio de Janeiro: Renovar, 1994, pp. 447-448.

58 Cf. ALEXY. Op. cit., pp. 86 e ss.

59 Além da obra básica de ALEXY, vide, a respeito do tema: CANOTILHO. Op. cit., pp. 1.0871.088; BARROSO, Luís Roberto. Temas de Direito Constitucional, cit., pp. 357-358.

60 Veja-se DWORKIN, Ronald. Los Derechos en Serio. Trad. Marta Guastavino. 1. ed. 4. reimp. Barcelona: Ariel, 1999, pp. 74-80.

61 Para uma exposição sintética e didática do assunto, vide: ALEXY, Robert. Op. cit., pp. 89 e 
Deve-se, ainda, salientar o importante papel desempenhado pelos princípios na ordem jurídica. Eles atuam como uma "conexão aglutinadora de normas" 62, isto é, têm a capacidade de ligar, de cimentar objetivamente todo o sistema jurídico, que assim adquire coerência lógica e unidade interna. Funcionam como um "fio condutor" dos diferentes segmentos da ordem jurídica, compatibilizando normas aparentemente contraditórias entre si $^{63}$ Apresentam também os princípios uma peculiar eficácia interpretativa, orientando especialmente a compreensão das normas que Ihes são subordinadas. ${ }^{64}$

Essas características típicas da eficácia jurídica dos princípios são apresentadas também, embora com certas peculiaridades, por aquelas normas que se convencionou chamar de programáticas. Trata-se, como se sabe, de normas jurídicas que impõem ao Estado certas finalidades a buscar ou valores a preservar. Por longo tempo consideradas como simples "exortações morais", ou meras proclamações de caráter político ou ético insertas nos textos legais, atualmente já não se nega - em virtude da sua incorporação ao Direito Positivo - a sua natureza verdadeiramente jurídica, e não apenas moral.

É certo que as normas programáticas acham-se mais intensamente presentes nas Constituições ditas compromissórias, como a nossa ${ }^{65}$ Talvez por esse motivo, a rica elaboração doutrinária acerca do tema se tenha desenvolvido com mais brilho e vigor no âmbito do Direito Constitucional, tanto no Brasil como alhures. ${ }^{66}$

ss.: CANOTILHO. Op. cit., pp. 1.161-1.165. Na doutrina brasileira mais recente, veja-se a ampla análise de SARMENTO, Daniel. A Ponderação de Bens na Constituição Federal. Rio de Janeiro: Lumen Juris, 2000.

62 CANARIS. Op. cit., p. 81.

63 Cf. BARROSO, Luís Roberto. Interpretação e Aplicação da Constituição, cit., p. 152, embora referindo-se especificamente aos principios constitucionais.

64 Cf. CRISAFULLI, Vezio. “I Principi Costituzionali dell'Interpretazione ed Applicazione delle Leggi”. In: Scritti Giuridici in Onore di Santi Romano, v. I. Milano: Dott. A. Giuffrè Editore, 1941, pp. 665 e ss.

65 As Constituições compromissórias - por oposição às Constituições doutrinárias - são aquelas que não se filiam a um único postulado ideológico, doutrinário ou filosófico, mas, ao contrário, expressam o conflito desenvolvido no seio da sociedade. Veja-se, a respeito, CANOTILHO. Op. cit., p. 141-143; CLÈVE, Clèmerson Merlin. A Teoria Constitucional e o Direito Alternativo: para uma Dogmática Constitucional Emancipatória. In: Uma Vida Dedicada ao Direito: Homenagem a Carlos Henrique de Carvalho. São Paulo: Revista dos Tribunais, 1998, p. 36.

66 Especialmente contribuíram para a compreensão do tema, citados em ordem de publicação da primeira edição da obra: CRISAFULLI, Vezio. La Costituzione e le sue Disposizioni di Principio, 1952, cit.; SILVA, José Afonso da. Aplicabilidade das Normas Constitucionais, 1968; RUSSOMANO, Rosah. "Das Normas Constitucionais Programáticas", 1976; GARCÍA DE ENTERRÍA, Eduardo. La Constitución como Norma y el Tribunal Constitucional, 1981; CANOTILHO, José Joaquim Gomes. Constituição Dirigente e Vinculaçāo do Legislador: Contributo para a Compreensão das Normas Constitucionais Programáticas, 1982; GRAU, Eros Roberto. "A Constituição Brasileira e as Normas Programáticas", 1985; BARROSO, Luís Roberto. O Direito Constitucional e a Efetividade de suas Normas: Limites e Possibilidades da Constituição Brasileira, 1989; SOMMERMANN, Karl-Peter. Staatsziele und Staatszielbestimmungen, 1997. 
Todavia, há normas programáticas em vários Diplomas legais infraconstitucionais, particularmente nas chamadas "leis-planos", ou "leis-medidas", ou "leis-quadros". Na Itália, Roberto Bin, em obra notável, faz um amplo levantamento dessas leis, demonstrando a enorme importância do tema para vários ramos do Direito que não o Constitucional ${ }^{67}$. Também no Brasil, não há como negar a grande proliferação dessas normas em nossa ordem jurídica infraconstitucional, sobretudo naquelas leis que, editadas pela União, veiculam as chamadas normas gerais a respeito de alguma matéria. Exemplo notório é o afamado Estatuto da Criança e do Adolescente (Lei 8.069 , de 13 de julho de 1990).

A Lei 10.257 , de 2001, que veicula as normas gerais, as "diretrizes" da política urbana, também incorpora essa tendência, como é natural em se tratando de um tema tão profundamente embebido de implicações sociais, econômicas e culturais. Dentre muitos outros exemplos, são normas programáticas vários incisos do art. $2^{\circ}$ desse Diploma:

“Art. $2^{\circ}$. A política urbana tem por objetivo ordenar o pleno desenvolvimento das funções sociais da cidade e da propriedade urbana, mediante as seguintes diretrizes gerais:

I - garantia do direito a cidades sustentáveis, entendido como o direito à terra urbana, à moradia, ao saneamento ambiental, à infra-estrutura urbana, ao transporte e aos serviços públicos, ao trabalho e ao lazer, para as presentes e futuras gerações;

II - gestão democrática por meio da participação da população e de associações representativas dos vários segmentos da comunidade na formulação, execução e acompanhamento de planos, programas e projetos de desenvolvimento urbano;

(...)

IV - planejamento do desenvolvimento das cidades, da distribuição espacial da população e das atividades econômicas do Município e do território sob sua área de influência, de modo a evitar e corrigir as distorções do crescimento urbano e seus efeitos negativos sobre o meio ambiente; (...)

IX - justa distribuição dos benefícios e ônus decorrentes do processo de urbanização".

Mesmo na definição da função social da propriedade urbana estão embutidos elementos programáticos:

“Art. 39. A propriedade urbana cumpre sua função social quando atende às exigências fundamentais de ordenação da cidade expressas no plano diretor, assegurando o atendimento das necessidades dos cidadãos quanto à quali-

67 BIN, Roberto. Atti Normativi e Norme Programmatiche. Milano: Dott. A. Giuffrè Editore, 1988, pp. 3 e ss. 
dade de vida, à justiça social e ao desenvolvimento das atividades econômicas, respeitadas as diretrizes previstas no art. $2^{\underline{0}}$ desta Lei."

A exemplificação poderia ocupar algumas páginas, mas nosso intuito imediato é apenas consignar que a Lei 10.257 , como lei nacional de normas gerais, acha-se bem sortida de normas programáticas, que se caracterizam, justamente, por apenas apontar fins, metas, objetivos.

Essas normas expressam $o$ que o Poder Público deve alcançar, mas não como esses objetivos serão realizados. Por isso, investem as pessoas numa posição jurídica menos consistente do que as normas de conduta típicas, pois não conferem aos seus beneficiários um direito subjetivo na sua feição tradicional, i.e. não ensejam, por si sós, a exigibilidade de determinada prestação, embora permitam a invalidação dos atos do Estado que as contrariem. ${ }^{68}$

Vem de longa data a tendência - que remonta aos escritos clássicos de Crisafulli sobre o tema - de considerar as normas programáticas como autênticos princípios jurídicos ${ }^{69}$, bem como de reconhecer aos princípios uma eficácia programática. Com efeito, a adoção de um princípio implica sempre na adoção de uma determinada linha de desenvolvimento do ordenamento jurídico. ${ }^{70}$ Deve-se a isso a equiparação que aqui se faz entre normas gerais, princípios e normas programáticas, que consubstanciam "diretrizes" - ou, para empregarmos a expressão de Dworkin, policies $^{71}$ - , produzindo efeitos jurídicos análogos, do ponto de vista prático.

\subsection{A necessária concretização das diretrizes gerais: o papel dos Municipios na sua adaptação aos problemas locais da cidade}

Uma das características fundamentais de uma Federação - ou, pelo menos, de uma verdadeira Federação - é a ausência de hierarquia entre os entes políticos que a integram ${ }^{72}$. A idéia de um escalonamento hierárquico de normas, presente na famosíssima metáfora da pirâmide, de Kelsen, embora possa servir muito bem para representar a relação existente entre os diferentes degraus da ordem jurídica ${ }^{73}$, levaria a equívocos se fosse transplantada para a realidade de um Estado Federal. Não existe, absolutamente, hierarquia entre União, Estados e Municípios; portanto, não há hierarquia, igualmente, entre leis federais, estaduais e municipais.

68 BARROSO, Luís Roberto. Interpretação e Aplicação da Constituição, cit., pp. 109-110.

69 Nesse sentido: CANOTILHO. Direito Constitucional e Teoria da Constituição, cit., p. 1.092; TORRES, Ricardo Lobo. Curso de Direito Financeiro e Tributário, cit., pp. 77-78; PIMENTA, Paulo Roberto Lyrio. Eficácia e Aplicabilidade das Normas Constitucionais Programáticas. São Paulo: Max Limonad, 1999, pp. 137-138.

70 Cf. CRISAFUlli. La Costituzione e le sue Disposizioni di Principio, cit., pp. 17, 41, 53-54.

71 DWORKIN, Ronald. Los Derechos en Serio, cit., p. 72.

72 DALLARI, Dalmo de Abreu. Elementos de Teoria Geral do Estado, cit., p. 218.

73 KELSEN, Hans. Teoria Pura do Direito. Trad. João Baptista Machado. 5. ed. São Paulo: Martins Fontes, 1996, pp. 246 e ss. 
O conceito jurídico de hierarquia é relativamente simples. Uma norma é hierarquicamente superior à outra quando lhe fornece o seu fundamento de validade. É precisamente o que se passa entre a Constituição - norma suprema - e a lei ordinária; e entre esta e o seu regulamento. Essa concepção gradualística da Escola de Viena, em que se vislumbra a formação do Direito por degraus, não se aplica aos entes federativos. O que existe entre União, Estados e Municípios não é hierarquia. mas divisão de tarefas ou - para empregarmos a expressão tecnicamente adequada - repartição constitucional de competências, já anteriormente referida.

Em outras palavras, ao exercer sua função legiferante, o Estado não o faz submisso à União; o Município, por sua vez, não o faz submisso nem à União, nem ao Estado a que pertence. Por isso não há hierarquia: os entes federativos menores não editam suas leis, não praticam seus atos retirando o fundamento de validade do ordenamento jurídico dos entes maiores. Todos os entes federativos, inclusive a União, retiram tal fundamento de validade, diretamente, da Constituição Federal, como "ato inaugural" do Estado. Assim, se uma lei municipal pretender regular matéria sobre a qual a União tem a primazia conferida pela Constituição, estaremos diante de uma lei municipal inconstitucional, porque ela viola a repartição de competências traçada na Lei Maior. Mas do mesmo vício padecerá a lei federal que invadir atribuições do Município: será uma lei federal, igualmente, inconstitucional. O que existe, portanto, entre os entes federativos é simplesmente uma "divisão de trabalho", uma repartição de competências previamente traçada pela Constituição.

Num Estado Federal, como o brasileiro, o conceito de autonomia - de que são dotados os entes federativos - pressupõe um poder de direito público não soberano, que pode, em virtude de direito próprio e não em virtude de delegação, estabelecer normas jurídicas obrigatórias. ${ }^{74}$ Vale dizer, "União, Estados e Municípios têm suas atribuições demarcadas pela Constituição Federal e estabelecem entre si relações que não têm a marca da hierarquia, mas a do desempenho, por legitimação própria, das funções constitucionalmente assinaladas" 75 .

Assim, de acordo com a repartição de competências realizada pela Constituição de 1988, o papel a ser desempenhado pelos Municípios em face da nova Lei de Diretrizes Urbanas apresenta dimensões generosas. Em primeiro lugar, esta amplitude decorre do próprio texto constitucional. Observe-se que, ao definir as competências legislativas privativas da União, a Constituição as enumera, dentro do elenco exaustivo do art. 22. A competência do Estado, por sua vez, é remanescente ou residual (art. $25, \S^{1}{ }^{\mathbf{0}}$ ). Já a competência do Município, embora seja expressa, não é enumerada: extrai-se da cláusula genérica que se refere a "interesse local".$^{76}$ Esta definição da competência em termos abertos, e não taxativos, abre uma imensa possibilidade de atuação ao Poder Público municipal.

74 Cf. BARACHO, José Alfredo de Oliveira. Teoria Geral do Federalismo, cit., p. 85.

75 BARROSO, Luís Roberto. "A Derrota da Federação: o Colapso Financeiro dos Estados $e$ Municípios". In: Temas de Direito Constitucional, cit., p. 142.

76 Cf. BARROSO, Luís Roberto. "Apontamentos sobre o Princípio da Legalidade". In: Temas de Direito Constitucional, cit., p. 184. 
Sempre que estiver presente o interesse local - expressão que veio substituir o "peculiar interesse" constante de Constituições anteriores ${ }^{77}$-, o Município terá a competência para legislar (art. 30, inc. I), aí incluída a possibilidade de suplementar a legislação federal e estadual no que couber (art. 30, inc. II). Em matéria de urbanismo, a competência é atribuída diretamente ao Município (art. 30, inc. VIII), sendo que, neste caso, as diretrizes gerais competem à União (art. 182, caput e § $\left.4^{0}\right)$. De fato, não há melhor exemplo de assunto de interesse predominantemente local do que o urbanismo, e aqui aplica-se plenamente o princípio da subsidiariedade: a atuação municipal tem preferência sobre a dos demais entes federativos. É aos Municípios que compete disciplinar, direta e pormenorizadamente, a matéria, dentro do quadro, da moldura principiológica traçada pela União através de uma lei nacional.

$\mathrm{O}$ conceito de interesse local - grande determinante da competência do $\mathrm{Mu}$ nicípio - merece um breve esclarecimento, pois trata-se de uma cláusula altamente genérica e de forte conteúdo fático. A melhor doutrina nacional, de que se cita como paradigma Hely Lopes Meirelles, pacificou-se no sentido de que se deve atentar não para a exclusividade do interesse local, mas para a sua predominância. Assim, quando a Constituição fala em "interesse local" — ou, nos textos anteriores a 1988, "peculiar interesse” dos Municípios ${ }^{78}$-, está fazendo referência a um interesse mais intensamente municipal, predominantemente local, que sobrepuja o interesse do Estado ou o da União. ${ }^{79}$

Além disso, o Prof. Diogo de Figueiredo Moreira Neto, com apoio em Adilson Dallari, observa que o conceito de interesse local tem um sentido dinâmico, sendo sensível às transformações tecnológicas e econômicas, e deve ter suficiente flexibilidade para assimilá-las, pois a predominância de interesse pode variar no tempo e no espaço ${ }^{80}$ Por isso, não se pode fixar a priori a amplitude do conteúdo da autonomia do Município, que depende da idéia que se faça de interesse local. ${ }^{81}$ Trata-se de um conceito histórico, que não pode ser avaliado desprendido do mundo dos fatos, devendo ser objeto de cuidadosa análise casuística pelo Poder Judiciário. Isto porque, sempre que predominar o interesse local sobre o regional e o nacional, ao Município deverá ser dada preferência na disciplina da matéria.

O destacado papel dos Municípios na política urbana também resulta de outra circunstância. As normas gerais, os princípios e as normas programáticas - espécies de normas veiculadas pela Lei 10.257 —, já se assinalou, só podem concretizar-se

77 Na Carta de 1967, com a redação dada pela Emenda n. 1, de 1969, a expressão "peculiar interesse" constava do art. 15 , inc. II.

78 Grande parte dos constitucionalistas pátrios entende que as expressões peculiar interesse e interesse local se equivalem, não tendo havido modificação de fundo com a adoção de nova expressão pela Carta de 1988. Veja-se, por exemplo, TEMER, Michel. Elementos de Direito Constitucional. 11. ed. São Paulo: Malheiros Editores, 1995, pp. 100-101.

79 Cf. MEIRELLES, Hely Lopes. Direito Municipal Brasileiro. 5. ed. São Paulo: Revista dos Tribunais, 1985, pp. 76-77.

80 MOREIRA NETO, Diogo de Figueiredo. Mutações do Direito Administrativo, cit., pp. 244-245.

81 JELLINEK, Georg. Teoría General del Estado, cit., p. 569. 
plenamente através de atos sucessivos que lhes dêem especificação e aplicabilidade. É absolutamente indispensável, para que as disposições de natureza principiológica possam realizar-se, a edição de normas ou atos a elas subordinados. Vale dizer. para as normas de caráter programático, a exigência de um ato estatal posterior (interpositio auctoritas) que as torne plenamente aplicáveis ao mundo dos fatos não é de ordem meramente técnica ou instrumental: a necessidade de uma normação posterior é, nesse caso, absolutamente essencial. inclusive do ponto de vista lógico. ${ }^{82}$ Há absoluta necessidade de um ato do Poder Público - no caso da política urbana, especialmente o Município - , seja legislativo ou administrativo, que venha determinar os meios pelos quais as diretrizes gerais estampadas na lei nacional serão concretizadas.

Em face desses aportes teóricos, não é necessário discorrer mais longamente sobre a ampla possibilidade de atuação reservada ao Município na adaptação dos princípios - unificados em âmbito nacional — aos problemas e à realidade local da cidade, o que se mostra proveitoso num país social e geograficamente heterogêneo como o Brasil.

\section{A cidade e os instrumentos da política urbana}

\subsection{A importância do Plano Diretor}

Determina o $\S 1^{\circ}$ do art. 182 , da Constituição, que "o plano diretor, aprovado pela Câmara Municipal, obrigatório para cidades com mais de vinte mil habitantes, é o instrumento básico da política de desenvolvimento e de expansão urbana". E a Lei 10.257 inclui o Plano Diretor como um dos instrumentos básicos da política urbana, fazendo parte do planejamento municipal (art. $4^{\circ}$, inc. III, $a$ ).

O Município é colocado, assim, como o grande formulador da política de desenvolvimento e expansão urbana, no sentido de ordenar as funções sociais da cidade e garantir o bem-estar de seus habitantes. Embora condicionado pela Lei de Diretrizes Urbanas, cabe ao Município delimitar sua zona urbana e sua área de expansão. A zona rural é definida residualmente, por remanescência: é toda aquela que não tenha sido delimitada pelo Município como espaço urbano. ${ }^{83}$

Esse problema de zoneamento traz uma implicação prática importantíssima, no que diz respeito ao ente político competente para promover a desapropriação: enquanto o imóvel rural que não esteja cumprindo sua função social pode ser desapropriado por interesse social pela União Federal (CF, art. 184), o imóvel urbano que não esteja cumprindo sua função social só pode ser desapropriado pelo Município (CF, art. 182, § $\left.4^{\circ}\right)$.

82 Cf. CRISAFUlLI, Vezio. La Costituzione e le sue Disposizioni di Principio, cit., p. 47; BONAVIDES, Paulo. Curso de Direito Constitucional, cit., p. 225.

83 MOREIRA NETO, Diogo de Figueiredo. Curso de Direito Administrativo, cit., p. 396. 
A Lei 10.257 , reafirmando o papel do Município como grande gerenciador da reforma urbana, procura efetivar, em várias de suas disposições, a função social da propriedade urbana, através de medidas que vão desde o parcelamento, edificação ou utilização compulsórios (arts. 5e e $6^{\circ}$ ), passando pelo IPTU progressivo no tempo (art. 7ㅇ), até a medida mais extrema, a desapropriação (art. 8º), aplicável somente quando o proprietário do imóvel urbano não houver cumprido a sua obrigação de parcelamento, edificação ou utilização decorridos cinco anos de cobrança do IPTU progressivo.

Assim, embora procurando preservá-lo, a Lei de Diretrizes Urbanas coloca o direito de propriedade como um verdadeiro direito exposto a condicionamento, conceito tão difundido na doutrina italiana: um direito que nasce perfeito, mas que pode vir a sofrer uma limitação, posteriormente, em virtude do interesse público, do bem comum, quando verificados certos pressupostos ${ }^{84}$. Essa função social da propriedade urbana é definida em termos principiológicos pelo art. 39, da Lei 10.257:

\begin{abstract}
"Art. 39. A propriedade urbana cumpre sua função social quando atende às exigências fundamentais de ordenação da cidade expressas no plano diretor, assegurando o atendimento das necessidades dos cidadãos quanto à qualidade de vida, à justiça social e ao desenvolvimento das atividades econômicas, respeitadas as diretrizes previstas no art. $2^{\underline{0}}$ desta Lei."
\end{abstract}

Também aqui, a concretização do princípio é deixada - como não poderia deixar de ser - ao Plano Diretor, que passou a ser obrigatório para cidades: (a) com mais de vinte mil habitantes; (b) integrantes de regiões metropolitanas ou aglomerações urbanas; (c) onde o Poder Público municipal pretenda impor o parcelamento ou edificação compulsórios, o IPTU progressivo no tempo e a desapropriação; (d) integrantes de áreas de especial interesse turístico; (e) inseridas na área de influência de empreendimentos ou atividades com significativo impacto ambiental de âmbito regional ou nacional. ${ }^{85}$

O Plano Diretor - que deve ser aprovado por lei municipal — não deixa também de ter um certo conteúdo programático, ao planificar o desenvolvimento e expansão urbana da cidade, traçando-lhe diretrizes e prioridades. Apesar desse caráter prospectivo e principiológico, ele vincula, no âmbito do Município, o plano plurianual, a lei de diretrizes orçamentárias e o orçamento anual (art. $40, \S 1^{\mathrm{O}}$ ), que devem necessariamente submeter-se ao Plano Diretor.

Além disso, o art. 42 da Lei 10.257 impõe ao Plano Diretor um conteúdo mínimo, de que se destaca a previsão de um sistema de acompanhamento e controle, consubstanciando a preocupação de assegurar-se o seu cumprimento e efetividade.

84 Cf. LANDI, Guido, POTENZA, Giuseppe. Manuale di Diritto Amministrativo. 7. ed. Milano: Dott. A. Giuffrè Editore, 1983, p. 148.

85 Cf. Lei 10.257 , art. 41. 


\subsection{A questão do zoneamento ambiental}

Úm dos pontos centrais do Direito Urbanístico é o problema do zoneamento, referente à destinação factual ou jurídica da terra às diversas modalidades de uso humano, sendo administrativamente fixada ou reconhecida. As duas destinações básicas são, como se sabe, a urbana e a rural. Por ser de estrito interesse local, a zona urbana é definida pelo próprio Município (CF, art. 30, inc. VIII), que nela distinguirá várias destinações, agrupadas em dois gêneros: residencial e não residencial. Esta, por sua vez, admite vários tipos de zonas: industriais, comerciais, portuárias, turísticas; pode haver, ainda, zonas mistas, desde que delimitadas com a devida cautela técnica. ${ }^{86}$

O zoneamento é um dos mais importantes instrumentos da política urbana, ao definir as atividades possíveis em determinados espaços territoriais, impedindo a sua ocupação anárquica e enquadrando-os em um determinado padrão de racionalidade. ${ }^{87}$

Manifestando a preocupação com o meio ambiente que marca os ordenamentos jurídicos contemporâneos, a Lei 10.257 inseriu, dentre os instrumentos da política urbana incluídos no planejamento do Município, o zoneamento ambiental (art. 4ํㅡ, inc. III, c), além de prever a realização, sempre que necessário, de estudo prévio de impacto ambiental (inc. VI).

A importância do zoneamento nessa matéria é de tal envergadura, que se chega a afirmar que, sem ele, não seria possível sequer pensar na própria existência do Direito Ambiental ${ }^{88}$. E também no zoneamento ambiental, os Municípios são os entes federativos aos quais se reservam as mais vastas tarefas, como, de resto, no zoneamento em geral. $O$ próprio estabelecimento das zonas urbanas e rurais, por exemplo, é da maior importância para a proteção do meio ambiente ${ }^{89}$.

Em última análise, compete aos Municípios, sobretudo através do Plano Diretor, conferir efetividade ao próprio art. 225 , da Constituição Federal, especialmente seus $\S \S 1^{\circ}$ e $4^{o}$, que impõem ao Poder Público e à comunidade em geral um dever de caráter dúplice: não promover a degradação ambiental e, ao mesmo tempo, promover a recuperação de áreas já eventualmente degradadas.

\subsection{A consensualidade na Administração Pública municipal}

Um dos aspectos mais interessantes assumidos pelo Direito Administrativo, na época atual, é uma preocupação cada vez maior não apenas com a legalidade dos atos da Administração, mas também com sua legitimidade, isto é, o necessário direcionamento à realização do interesse público, à concretização dos anseios sociais. O Estado contemporâneo vai perdendo, pouco a pouco, uma certa postura "imperial"

86 Cf. MOREIRA NETO, Diogo de Figueiredo. Curso de Direito Administrativo, cit., pp. 396-397.

87 ANTUNES. Paulo de Bessa. Direito Ambiental. 5. ed. Rio de Janeiro: Lumen Juris, 2001, p. 131 .

88 Id., ibid., p. 134.

89 ld., ibid., p. 136. 
de grande monopolista do interesse público, e readquirindo o seu caráter de instrumento da sociedade.

Ganha prestígio, nesse panorama, o princípio da consensualidade, determinando a substituição, sempre que possível, da imperatividade pelo consenso nas relações Estado-sociedade, e a criação de atrativos para que os entes da sociedade civil atuem em parceria com o Estado. Ampliam-se, nesse processo, as vias de cooperação entre os entes públicos e de colaboração entre os entes públicos e particulares, além dos fenômenos de desestatização, despolitização e deslegalizaçãoo ${ }^{90}$

Valorizam-se, com isso, institutos que aproximam a sociedade do Poder Público, como os instrumentos da democracia direta (plebiscito, referendo, iniciativa popular), a coleta de opinião, o debate público, a audiência pública e a chamada delegação atípica, outorgada às entidades intermédias. ${ }^{91}$

Recepcionando essas novas tendências do moderno Direito Administrativo, a Lei 10.257 prevê uma série de instrumentos viabilizadores de uma autêntica "Administração consensual" da cidade.

Um desses instrumentos são as operações urbanas consorciadas (arts. 32 a 34), coordenadas pelo Poder Público municipal, com a participação de proprietários, moradores, usuários e investidores privados, com o objetivo de alcançar, numa certa área, transformações urbanísticas estruturais, melhorias sociais e valorização ambiental. Também o art. 43 consigna diversos instrumentos tendentes a uma "gestão democrática da cidade", dentre os quais debates, audiências e consultas públicas.

Esses instrumentos participativos estão igualmente previstos no processo de elaboração do Plano Diretor e na fiscalização de sua execução (art. 40, § 4ํo), bem como na gestão do orçamento (art. $4^{\circ}$, inc. III, $f$, e art. 44).

As vantagens da aplicação prática desses institutos são evidentes, sobretudo em cidades complexas e com os problemas sociais típicos das grandes metrópoles. Resta ao Poder Público municipal o alto papel de conferir efetividade a essas disposições extremamente democráticas da nova Lei de Diretrizes Urbanas.

\section{Conclusão}

A seguir, são compendiadas algumas considerações conclusivas deste trabalho, apresentando-se sinteticamente as principais idéias desenvolvidas ao longo da exposição.

1. A Constituição de 1988 confere aos Municípios, no Brasil, o status de verdadeiros entes federativos. Embora em desacordo com a noção clássica de Federação, essa inovação garante-lhes uma ampla autonomia, que deve ser levada em conta e protegida no processo de interpretação constitucional.

90 Confira-se, para uma análise geral dessas questões atuais do Direito Público, MOREIRA NETO, Diogo de Figueiredo. Mutações do Direito Administrativo, cit., especialmente pp. 7-48.

91 Id., ibid., p. 14. 
2. Em matéria de política urbana, a repartição constitucional de competências atribui à União as normas gerais, aos Estados as normas regionais e aos Municípios as normas locais. Sempre que estiver presente o interesse local preponderante, o princípio da subsidiariedade confere primazia ao próprio Município para a disciplina da matéria.

3. A Lei 10.257 , de 2001 , que veicula as diretrizes gerais da política urbana, como lei nacional, apresenta normas que ostentam, tipicamente, a eficácia principiológica - como as normas programáticas - , que necessitam de uma posterior integração pela legislação específica, produzida sobretudo em nível municipal. Não havendo hierarquia entre os entes federativos, é necessário que cada qual se restrinja à sua esfera própria de competências, de modo que fique resguardada a autonomia municipal em matéria de política urbana.

4. A Lei 10.257 transfere ao Município um papel preponderante na condução da política urbana da cidade, colocando-o como grande força motriz de uma autêntica reforma urbana, a concretizar a função social da propriedade. Isto se dá, especialmente, através do Plano Diretor, ao qual é atribuída uma força vinculante bastante contundente. Também no que diz respeito ao zoneamento, o Município assume largas tarefas no sentido da preservação ambiental.

5. A nova Lei de Diretrizes Urbanas prevê diversos instrumentos aptos a aproximar a Administração Pública municipal dos cidadãos e da sociedade. Afirma-se, desta forma, o princípio da consensualidade, através das operações urbanas consorciadas, da chamada gestão democrática da cidade, do orçamento participativo e da participação da cidadania na elaboração do Plano Diretor, assim como na fiscalização de sua implementação. Cabe sobretudo ao Poder municipal dar operatividade prática a esses institutos democráticos.

\section{Referências bibliográficas}

AGUILERA DE PRAT, Cesáreo R., VILANOVA, Pere. Temas de Ciência Política. Barcelona: Promociones Publicaciones Universitarias, 1987.

ALEXY, Robert. Teoría de los Derechos Fundamentales. Trad. Ernesto Garzón Valdéz. Madrid: Centro de Estudios Constitucionales, 1993.

ALVES, Francisco de Assis. Constituiçōes do Brasil. Revista de Direito Constitucional e Ciência Política, n. especial. Rio de Janeiro: IBDC/Forense, 1987.

ANTUNES, Paulo de Bessa. Direito Ambiental. 5. ed. Rio de Janeiro: Lumen Juris, 2001.

ASCENSÃO, José de Oliveira. O Direito. Introdução e Teoria Geral: uma Perspectiva Luso-brasileira. Rio de Janeiro: Renovar, 1994.

BARACHO, José Alfredo de Oliveira. Princípio da Subsidiariedade: Conceito e Evolução. Rio de Janeiro: Forense, 1996.

Teoria Geral do Federalismo. Rio de Janeiro: Forense, 1986.

BARROSO, Luís Roberto. Direito Constitucional Brasileiro: o Problema da Federação. Rio de Janeiro: Forense, 1982. 
O Direito Constitucional e a Efetividade de suas Normas: Limites $e$ Possibilidades da Constituição Brasileira. 2. ed. Rio de Janeiro: Renovar, 1993. - Interpretação e Aplicação da Constituição: Fundamentos de uma Dogmática Constitucional Transformadora. 3. ed. São Paulo: Saraiva, 1999.

\section{- Temas de Direito Constitucional. Rio de Janeiro: Renovar, 2001.}

BASTOS, Celso Ribeiro, MARTINS, Ives Gandra da Silva. Comentários à Constituição do Brasil, v. 1. São Paulo: Saraiva, 1988.

BIN, Roberto. Atti Normativi e Norme Programmatiche. Milano: Dott. A. Giuffrè Editore, 1988.

BOBBIO, Norberto. Teoria do Ordenamento Jurídico. Trad. Maria Celeste dos Santos. 10. ed. Brasília: Ed. Universidade de Brasília, 1997.

BONA VIDES, Paulo. Curso de Direito Constitucional. 9. ed. São Paulo: Malheiros Editores, 2000.

CANARIS, Claus-Wilhelm. Pensamento Sistemático e Conceito de Sistema na Ciência do Direito. Trad. António Menezes Cordeiro. 2. ed. Lisboa: Fund. Calouste Gulbenkian, 1996.

CANOTILHO, José Joaquim Gomes. Direito Constitucional e Teoria da Constituição. 3. ed. Coimbra: Almedina, 1999.

CLËVE, Clèmerson Merlin. A Teoria Constitucional e o Direito Alternativo: para uma Dogmática Constitucional Emancipatória. Uma Vida Dedicada ao Direito: Homenagem a Carlos Henrique de Carvalho. São Paulo: Revista dos Tribunais, 1998.

CRISAFUlLI, Vezio. La Costituzione e le sue Disposizioni di Principio. Milano: Dott. A. Giuffrè Editore, 1952.

I Principi Costituzionali dell'Interpretazione ed Applicazione delle Leggi. Scritti Giuridici in Onore di Santi Romano, v. I. Milano: Dott. A. Giuffrè Editore, 1941.

DALLARI, Dalmo de Abreu. Elementos de Teoria Geral do Estado. 18. ed. São Paulo: Saraiva, 1994.

DROMI, Roberto. Ciudad y Município. Buenos Aires: Ediciones Ciudad Argentina, 1997.

DWORKIN, Ronald. Los Derechos en Serio. Trad. Marta Guastavino. 4. reimp. Barcelona: Ariel, 1999.

EHMKE, Horst. Prinzipien der Verfassungsinterpretation. Veröffentlichungen der Vereinigung der Deutschen Staatsrechtslehrer, H. 20. Berlin: Walter de Gruyter \& Co., 1963.

FAUSTO, Boris. História do Brasil. 4. ed. São Paulo: Editora da USP, 1996.

FUSTEL DE COULANGES, Numa Denis. A Cidade Antiga. Trad. Fernando de Aguiar. 4. ed. São Paulo: Martins Fontes, 1998.

GARCÍA DE ENTERRÍA, Eduardo. La Constitución como Norma y el Tribunal Constitucional. 3. ed. 3. reimp. Madrid: Civitas, 1994.

HORTA, Raul Machado. Direito Constitucional. 2. ed. Belo Horizonte: Del Rey, 1999.

JELLINEK, Georg. Teoría General del Estado. Trad. Fernando de los Ríos. México: Fondo de Cultura Económica, 2000. 
KELSEN, Hans. Teoria Pura do Direito. Trad. João Baptista Machado. 5. ed. São Paulo: Martins Fontes, 1996.

LANDI. Guido, POTENZA, Giuseppe. Manuale di Diritto Amministrativo. 7. ed. Milano: Dott. A. Giuffrè, 1983.

LARENZ, Karl. Derecho Justo: Fundamentos de Ética Jurídica. Trad. Luís Díez-Picazo. Madrid: Civitas, 1993.

LEAL. Victor Nunes. Coronelismo, Enxada e Voto. 4. ed. São Paulo: Alfa Ômega. 1978.

LOEWENSTEIN, Karl. Teoría de la Constitución. Trad. Alfredo Gallego Anabitarte. Barcelona: Ariel, 1965.

MEIRELLES, Hely Lopes. Direito Municipal Brasileiro. 5. ed. São Paulo: RT: 1985. MIRANDA, Jorge. Manual de Direito Constitucional. t. II. 3. ed. Coimbra: Coimbra Editora, 1996.

MIRANDA, Pontes de. Comentários à Constituição de 1946. v. I. Rio de Janeiro: Henrique Cahen Editor, 1947.

MORAES, Alexandre de. Direito Constitucional. 8. ed. São Paulo: Atlas, 2000.

MOREIRA NETO, Diogo de Figueiredo. Curso de Direito Administrativo. 11. ed. Rio de Janeiro: Forense, 1999.

Mutações do Direito Administrativo. Rio de Janeiro: Renovar, 2000.

Cidadania e Advocacia no Estado Democrático de Direito. Revista da Procuradoria Geral do Estado do Rio de Janeiro, n. 50, 1997.

NOVELLI, Flávio Bauer. A Eficácia do Ato Administrativo. Revista de Direito Administrativo, v. 60/61, 1960.

SANCHEZ AGESTA, Luís. Princípios de Teoría Política. Madrid: Nacional, 1983. TEMER, Michel. Elementos de Direito Constitucional. 11. ed. São Paulo: Malheiros Editores, 1995.

TORRES, Ricardo Lobo. Curso de Direito Financeiro e Tributário. 7. ed. Rio de Janeiro: Renovar, 2000.

TORRES, Silvia Faber. O Princípio da Subsidiariedade no Direito Público Contemporâneo. Rio de Janeiro: Renovar, 2001. 